\title{
SPONDYLITIS FOLLOWING WEIL'S DISEASE
}

\author{
BY \\ J. H. JACOBS \\ From the Rheumatism Unit, St. Stephen's Hospital, London
}

Cases of infective spondylitis following typhoid, paratyphoid, undulant fever, and gonococcal and staphylococcal infections are well recorded, and Brailsford (1948) reports arthritis of the spine as a complication of most of the infectious diseases. Ashe and others (1941), in their review of the world's literature on Weil's disease, record meningitis, leptospiral endocarditis, peripheral neuritis, optic atrophy, and iridocyclitis as complications, but no case of spondylitis following this infection appears to have been reported.

The early radiological changes occurring in infective spondylitis may be confined to narrowing of the intervertebral disk spaces and osteoporosis of the neighbouring bone. This is later followed by loss of bony detail, small marginal erosions, and sclerosis of the opposing surfaces of the bodies, with bridging between them and possibly ultimate fusion of the vertebrae. Paravertebral abscesses may also be present.

\section{Case History}

A man, aged 59, a plumber by trade, was admitted to hospital on 13 April, 1949, with a history of lassitude and shivering attacks for a week, and jaundice for the last two days. He stated that he had been working in a rat-infested factory until a week before admission. Examination revealed a febrile, drowsy, dehydrated, jaundiced man with purpuric spots on his trunk. A clinical diagnosis of sub-acute hepatic necrosis was made.

Blood Examination.-White-cell count 13,300; agglutinations positive to Leptospira icterohaemorrhagica to $1: 1,000$, but negative to $L$. canicola.

Three weeks later, white-cell count 25,000 ; agglutinations positive to $L$. icterohaemorrhagica to $1: 3,000$, and positive to $L$. canicola up to a titre of $1: 300$. Agglutinations positive to $B$. typhosus $H$. to $1: 50$, but negative to $B$. typhosus $O, B$. paratyphosus $A$ and $B$, and Brucella abortus.

Treatment.-He was treated with penicillin and improved after a slow and stormy course, but discharged himself from hospital on May 30, although still unable to walk. He does not remember suffering from pain in his back while in hospital, although an $x$ ray of his spine taken on May 12,1949, showed some osteo-arthritic changes in the middorsal region and no other abnormality.

Later Developments.-After returning home he complained of pain across his back on attempting to get up, and he remained bed-ridden until November 16, 1949, when he was seen in the Rheumatic Unit and admitted to the wards. 
Examination revealed a wasted individual with a stiff spine, tender to percussion in the lower dorsal area. All movements were limited at the right hip. On questioning he denied having suffered from pain in his hips or spine prior to this illness, saying that he had not lost a day off work for 14 years on account of illness.

Blood Examination.-Red-cell count 3,600,000; haemoglobin 74 per cent.; white-cell count 14,400; alkaline phosphatase 10 units; acid phosphatase $3 \cdot 2$ units; blood sedimentation rate 90; Wassermann reaction negative; agglutinations positive to $L$. icterohaemorrhagica to $1: 100, L$. canicola to $1: 10$, and B. typhosus $H 1: 25$; negative to $B$. typhosus $O$, paratyphoid, and Br. abortus.

$X$-Ray Examination.-November 22, 1949. A considerable increase had taken place in osteophytes in the lower five dorsal and upper three lumbar vertebrae with massive outgrowths. The disk spaces in this area were all markedly narrowed with marginal erosions and loss of definition of the bone structure of the vertebral bodies. The intervertebral joints in the upper lumbar area appeared normal and there was no evidence of paravertebral abscess. The right hip was internally rotated. There were heavy osteophytic deposits on the acetabulum with erosions of the articular cartilage of the femoral head and acetabulum with some sub-articular erosions (Fig. 1). The left hip showed some degenerative changes, but not beyond normal limits for his age.

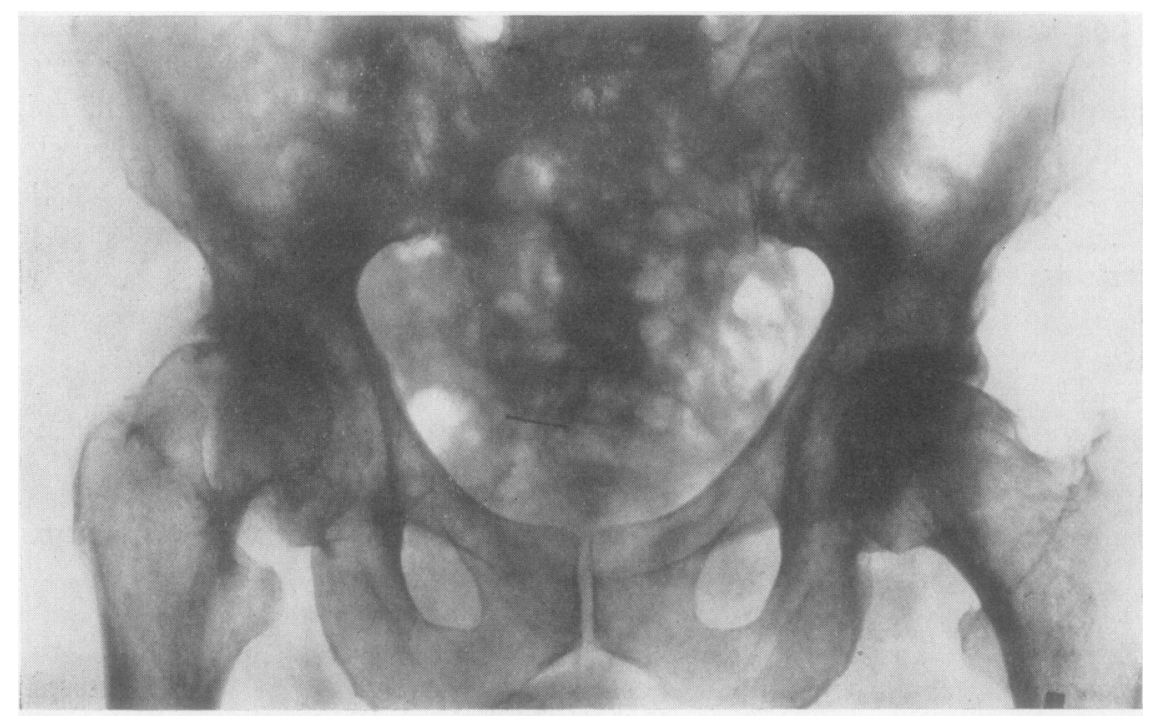

FIG. 1.-Radiograph of hips, showing osteo-arthritic changes in right hip, November 25, 1949.

Treatment.- He was given a further course of penicillin and a spinal jacket was fitted on February 10, 1950, By March 20, 1950, four months after admission, he was free from pain and able to walk in his jacket; the blood sedimentation rate had fallen to 50. $X$ rays taken in July, 1950, just before discharge showed an increase in the size of the osteophytes and erosions in the vertebrae with a further decrease of the disk spaces and spread of the lesion to the seventh dorsal and fourth lumbar vertebrae (Figs 2 and 3). There were no further radiological changes in his hips. 


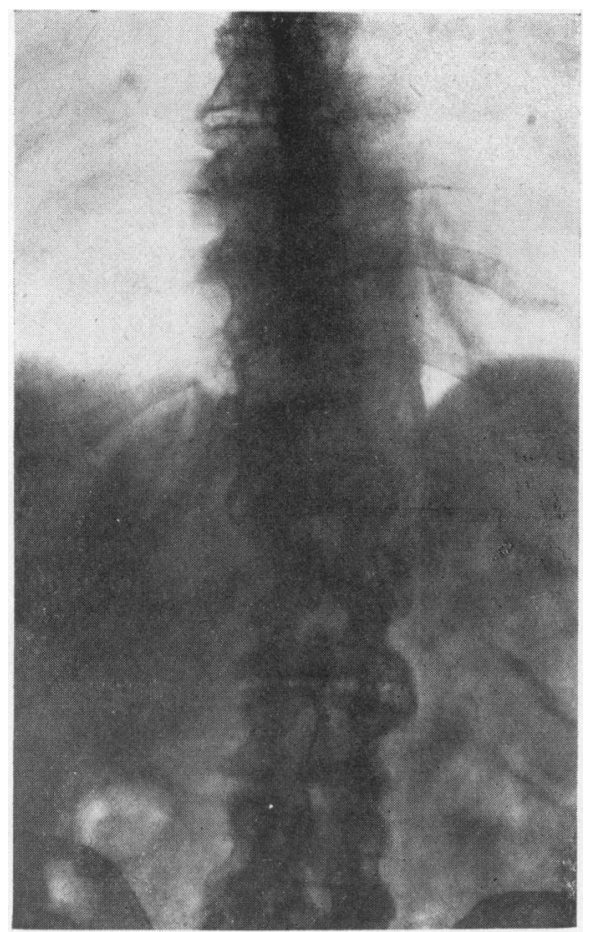

FIG. 2.-Radiograph of spine, showing progressive narrowing of intervertebral disk spaces with ankylosis, July 21, 1950.

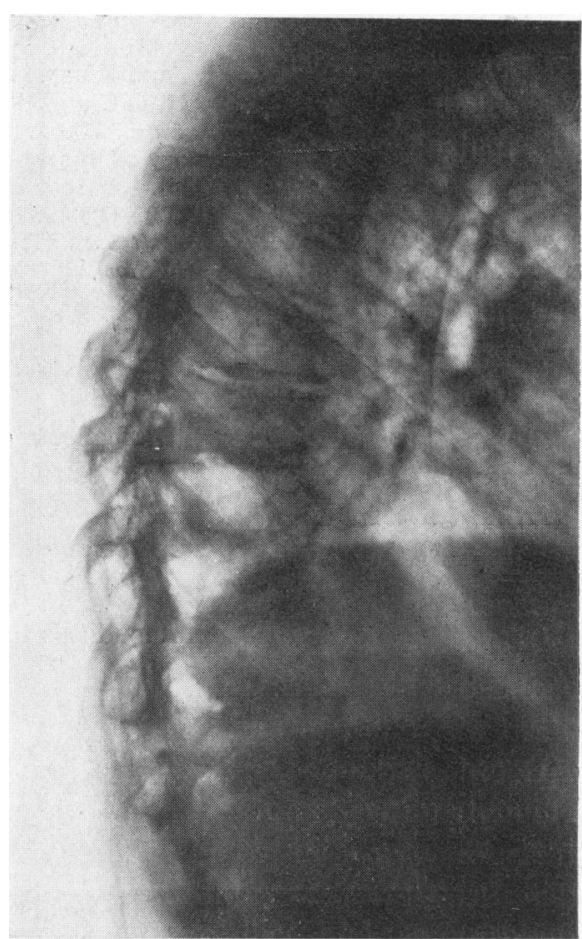

FIG. 3.-Lateral view of spine, showing marginal erosions, July 21, 1950.

\section{Discussion}

This patient first noticed severe pain in his back some four months after an infection with $L$. icterohaemorrhagica. The radiological appearances were those of an infective spondylitis and it is interesting to note that in both typhoid and brucellosis, spondylitis may occur many months after the original infection. Keith and Keith (1926) noted that in typhoid bony deposits may already be present in the lateral ligaments by the time the patient first complains of backache.

No films of this patient's hips before his illness are available, but he states he was able to work normally up to this time. When seen six months after his original discharge from hospital there was considerable limitation of movement in the right hip, with osteophytic outgrowths and erosions in the head of the femur and acetabulum, and it is not unlikely that these changes are similar in origin to those described in his spine.

\section{Summary}

A case of infective spondylitis with involvement of one hip following an attack of Weil's disease is described.

I should like to thank Dr. Francis Bach and Mr. H. E. Harding for their interest in this case, and Dr. Grace Batten for her considerable help with the radiology. 


\section{REFERENCES}

Ashe, W. F., Pratt-Thomas, H. R., and Kumpe, C. W. (1941). Medicine, Baltimore, $20,145$.

Bade, H. (1939). Röntgenpraxis, 11, 461.

Bishop, W. A. (1939). J. Bone Jt Surg., 21, 665.

Brailsford, J. F. (1948). " Radiology of Bones and Joints", 4th ed. Churchill, London.

Keith, D. Y., and Keith, J. P. (1926). J. Amer. med. Ass., 87, 2145.

Kulowski, J., and Vinke, T. H. (1932). Ibid., 99, 1656.

O'Donoghue, A. F. (1933). J. Bone Jt Surg., 15, 506.

Sandström, O. (1937). Acta radiol., Stockh., 18, 253.

Spondylite à la Suite de la Maladie de Weil

RÉSUMÉ

On décrit un cas de spondylite infectieuse affectant une hanche et survenant après une attaque de la maladie de Weil.

\section{Espondilitis Consecutiva a la Enfermedad de Weil}

\section{RESUMEN}

Descripción de un caso de espondilitis infecciosa en una cadera, ocurriendo despuès de un ataque de la enfermedad de Weil. 